\title{
Creating a Child-Friendly Child Welfare System: The Use and Misuse of Research
}

\section{Citation}

Elizabeth Bartholet, Creating a Child-Friendly Child Welfare System: The Use and Misuse of Research (May 10, 2013)(unpublished manuscript)(on file with author).

\section{Permanent link}

http://nrs.harvard.edu/urn-3:HUL.InstRepos:10777661

\section{Terms of Use}

This article was downloaded from Harvard University's DASH repository, and is made available under the terms and conditions applicable to Open Access Policy Articles, as set forth at http:// nrs.harvard.edu/urn-3:HUL.InstRepos:dash.current.terms-of-use\#OAP

\section{Share Your Story}

The Harvard community has made this article openly available.

Please share how this access benefits you. Submit a story.

\section{Accessibility}




\section{Creating a Child-Friendly Child Welfare System:}

The Use and Misuse of Research

Elizabeth Bartholet ${ }^{1}$

\section{INTRODUCTION}

It is truly an honor and pleasure to be here. I was here nine years ago, in January of 2004, presenting this same FitzRandolph Lecture, and was impressed then as I am now with your leadership in child rights advocacy and education.

My topic then was problems and progress in the child welfare field. I gave that talk during a moment of optimism. My emphasis was on progress. The Multiethnic Placement Act had just, for the first time, been enforced by the U.S. Department of Health \& Human Services, imposing on the state violating the Act a whopping financial penalty.

But in reviewing that 2004 talk's descriptions of problems, I found myself discouraged to realize that many of those same problems exist today. They are related to my topic here.

There is, however, one piece of progress I want to report. Shortly after my 2004 visit, we created at Harvard Law School a Child Advocacy Program, inspired at least in part by your program. We hoped that we might in turn inspire other law schools to create such programs -programs designed to educate law students about child and youth issues, and to encourage law students to make this work their work.

A major theme of our program is the importance of thinking broadly about advocacy - thinking outside the courtroom. We want our students to understand that there are many really serious problems with how children and youth are treated in our society. And there's a limited amount you can do in a courtroom to accomplish the kind of profound social change needed. That's

\footnotetext{
${ }^{1}$ Professor of Law, Harvard Law School. This article is a slightly revised version of the FitzRandolph Memorial Lecture I gave at the Center for Children's Rights, Whittier Law School, February 5, 2013. That lecture was based in significant part on my article, Creating a Child-Friendly Child Welfare System: Effective Early Intervention to Prevent Maltreatment and Protect Victimized Children, 60 Buffalo L. Rev. 1323 (2012). Documentation for various points made here is contained in that article.
} 
true whether you do individual legal services work or class action law reform work. I say this even though I believe litigation can be a useful tool for change. Prior to joining the law faculty at Harvard, I spent much of my life as a lawyer engaged in class action law reform work. But I think that to use the courtroom effectively you need to work across disciplines and to join forces with others working in other arenas, with for example social scientists, legislators, and grass roots organizers. We also hope that many of our students will think of working not specifically as courtroom lawyers but as players in these other arenas, including as forces for reform from within child welfare, education and juvenile justice systems.

One point we stress with our students is the unique challenge of child advocacy work. I have always worked on behalf of people at the bottom of the power hierarchy. I did civil rights work with the NAACP Legal Defense Fund, working on behalf of African-Americans. I started a public interest law firm called the Legal Action Center, and focused its work on some of society's ultimate outcasts, ex-addicts and ex-offenders. But I think children are uniquely disempowered because by definition they can't make decisions, demonstrate on the streets, vote, or do any of those things that other disempowered groups can do to protect their interests. And since adults are inevitably the ones making the decisions, children are at risk of being pawns in some adult-oriented battle.

You students who have chosen to be here today, and to be part of the Whittier Center for Children's Rights, have taken up this challenge. You are in a position to shape the child welfare policy of the future.

\section{MY TOPIC}

My topic today: Creating a Child-Friendly Child Welfare System: The Use and Misuse of Research. We have what we call a child welfare system, that is supposed to be protect children against parental abuse and neglect. But does this system really serve child welfare? In my view, it does not. Instead the system largely serves various adult interests, and is often quite hostile to children.

My topic more specifically is child welfare research. This field is blessed with an unusual amount of research, research that provides the potential to shape policy in ways that would serve kids. In my own work I have found the research hugely helpful in thinking through policy issues.

So, for example, I was guided by the research in thinking about transracial adoption. When I first looked at this issue in the 1980s, many condemned such adoption as causing racial identity confusion and other problems for children. These claims were used to justify strict race- 
matching policies designed to ensure that children were raised by same-race parents. Race matching in turn resulted in delays in placing children in adoption, and often the denial of adoption altogether, since there were many more white than black prospective adoptive parents. I set out to read all the social science related to the issue and found that it called for a dramatic change in policy. The social science showed clearly that what kids need as early in life as possible is a good nurturing home. And that, actually, the skin color of the parent doesn't much matter. What matters is that someone loving is there, prepared to get up in the middle of the night and take care of the child, committed to being there for the child forever.

I was similarly guided by the research in discovering the value of early home visitation programs. Few interventions have any demonstrated success in improving parents' ability to provide nurturing care and avoid maltreatment. But one program stood out based on its research - the Nurse Practitioner model of home visitation designed by David Olds. His research demonstrated convincingly both that his particular model of home visitation helps reduce the levels of child maltreatment, and that it is cost-effective within a relatively short period of time. Both findings are hugely important. Cost-effectiveness may be key to actually getting promising reforms adopted in a world of scarce resources.

I will focus today on the misuse of research. I will talk about the deliberate promulgation of bad research, and the use of that research to promote bad policy.

My claim is that overall the research in this field is skewed in an adult-rights direction for the very same reasons that policy is skewed in that direction. And this should be no surprise because the same entities fund the research as fund policy advocacy -- a small set of monumentally wealthy private foundations. I'm all for advocacy by private entities. We should not leave policy entirely to the government. But there is a danger when you have politically unaccountable private foundations playing a huge role both in policy advocacy, and in the research that's supposed to illuminate policy decision-making. That danger has played out in this child welfare area.

So here's another reason that you in this room are tremendously important. There is a lot of research out there. It isn't that easy to understand the research and to tell good research from bad. We need good, trained advocates analyzing this research, assessing its relevance for policy, and encouraging the development of the right kind of research in the future.

I'm going to talk about one example of good research ignored, and then two examples of bad research deliberately promulgated to promote bad policy. 


\section{GOOD RESEARCH IGNORED}

Here I will talk about one of my favorite topics, international adoption, which I see as one way only one way, but an amazingly successful way -- to actually help some children in desperate need.

Policy makers are rapidly eliminating international adoption as an option for children. They defend this action based largely on claims about child best interests, claims that children are best off if kept within their country of origin.

Those making these claims and arguing for the reduction or elimination of international adoption describe themselves as the child welfare people, the child human rights people. the key organizations are UNICEF, Save the Children, the U.N. Committee on the Rights of the Child, and other such.

You get a sense for the political players if you look at the amicus briefs filed opposing Madonna's adoptions in Malawi. The Malawi courts upheld her adoptions saying that the only other option for each of the two children she adopted would have been life in an institution. These courts held that relegating children who could be adopted to life in an institution would violate their human rights.

But the amicus briefs filed in the second case included 85 self-styled child human rights organizations led by Save the Children, opposing the adoptions. Not a single child human rights organization joined the side supporting the adoptions in either case. That's the official child human rights position. This is part of why virtually every article I've written in recent history on this international adoption topic has had "human rights" in the title. International adoption is being shut down by the human rights community, or at least people speaking in that community's name.

Nationalist forces contribute to the problem, as illustrated by Russia's recent shutdown of international adoption to the U.S. Russia made a refreshingly honest statement of national interest: We want to punish the U.S. by denying them our children because the U.S. acted to punish us with its Magnitsky Act.

This chart shows what's going on -- after six decades of a steady rise in international adoption, you get almost 23,000 children finding homes in the U.S. in 2004 . The numbers then drop off a cliff so that by 2013 it's projected that the total will be down to one-third of the 2004 figure. 


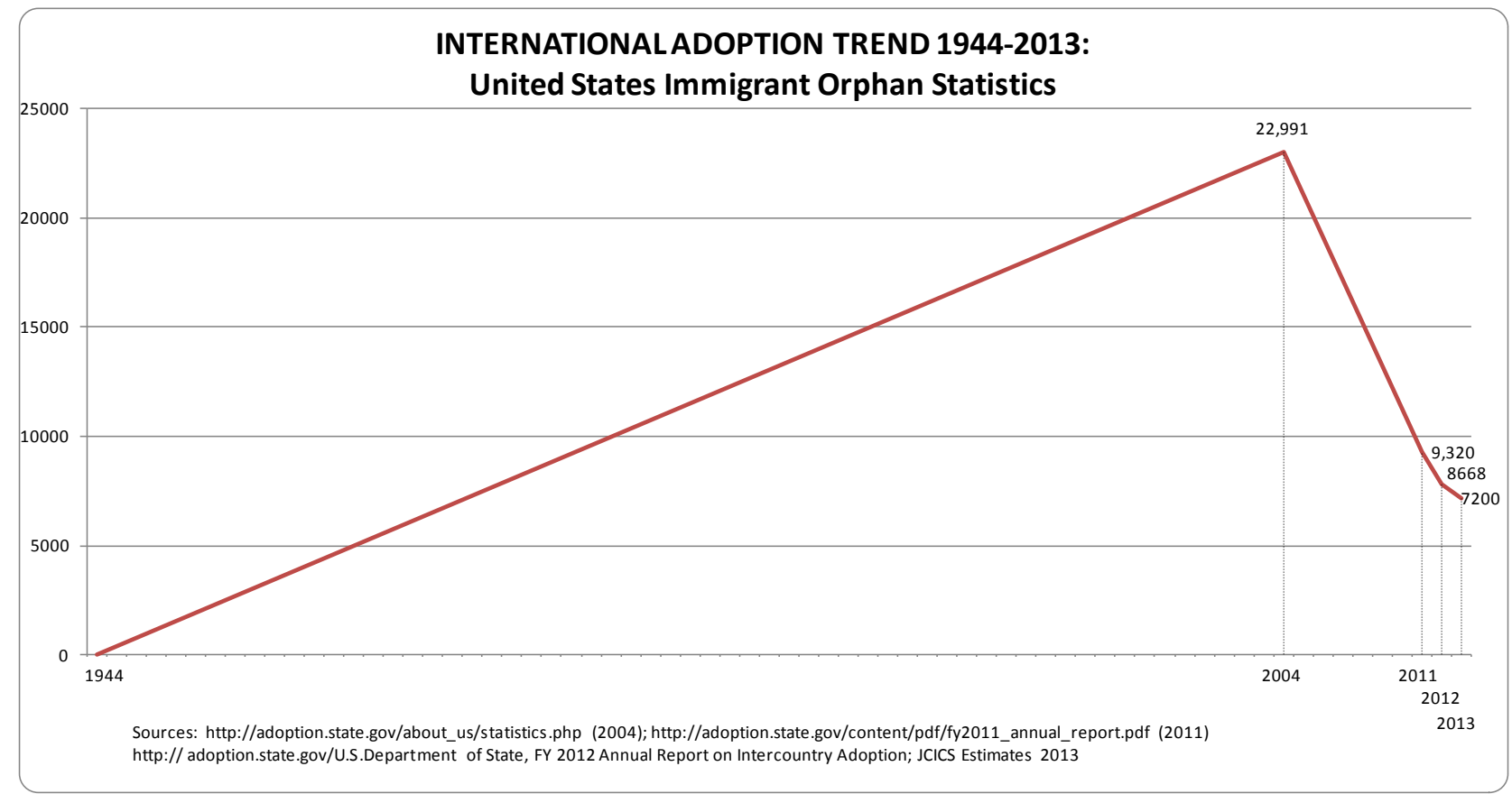

That's pretty dramatic in terms of what's happening. And my claim, of which I feel 100 percent sure, is that this decline has nothing to do with any decline in the needs of children. The needs of children worldwide have only increased since 2004 in terms of the number of orphans, the number of kids in institutions, the number of unparented children in need of a nurturing home. Nor has the number of potential adoptive parents declined.

What has happened is that those who think international adoption is problematic have focused on that upward trajectory and said No. This is a problem. We will now target every single country that sends significant numbers of kids out in international adoption and we will bring a stop to this.

So that's the policy. Let's shut it down. And it's the policy affecting all international adoption, not just into the U.S. Worldwide the figures were down as of 2012 to roughly half the 2004 number.

A related development is that the kids placed internationally today tend to be two to three years old or older, having spent that time almost always in an institution, which is almost always horrendously destructive of their future life opportunities, as well a seriously rotten place to spend any period of time. This by contrast to earlier policy enabling at least many children to be placed in infancy, giving them an excellent chance for healthy development, emotional, intellectual, and physical.

So that's what the policy makers are doing. Now, what does the research show? 
The research shows that this falling-off-a-cliff phenomenon is a tragedy for children, destructive of their most fundamental human rights to grow up in a way enabling the enjoyment of their future human rights as adults. And it's not just a tragedy. It's a deliberate evil because this is intentionally chosen policy.

Why do I say this is what the research shows? Well, the research shows institutions, even the ones that anybody ever has chosen to label "good" institutions, are incredibly bad for kids.

The research shows the in-country options that anti-international adoption forces promote either aren't going to happen or aren't going to work for kids. UNICEF's position is that international adoption should be a last resort, maybe conceivably allowed once in a while. UNICEF never promotes such adoption as a solution for kids in need. If you read UNICEF reports on what to do about the many millions of needy orphans in the world, they never mention international adoption. These reports specify everything but such adoption as solutions, including group homes and sibling-headed households. UNICEF official policy promotes incountry foster care as a preferable option for children to international adoption. UNICEF also promotes in-country adoption. But neither foster care nor adoption exist to any significant degree in the countries with large populations of unparented children. Nor will they in any near future. Indeed most of the countries at issue are severely biased against adoption.

Moreover, the research indicates that adoption works far better for children than foster care, and of course far better than group homes or sibling-headed households or institutions. The research demonstrates that adoption generally works amazingly well for kids, helping them to recover from damage suffered, and enabling those who haven't suffered too much damage to develop comparably with children born into and raised by untroubled families.

The research fails even to justify a preference for in-country adoption from the child's viewpoint. It doesn't really matter whether children are adopted within their nation of origin or across racial and national lines of difference. What matters is that they are adopted, as early in life as possible.

The research, together with the obvious facts, also shows what's going to happen to the kids that don't get out when countries shut down international adoption. We can look at the countries that in recent years have shut down or severely cut down international adoption, countries like Guatemala, Russia, Romania. What happens is that children who might have gotten international adoptive homes stay in institutions. So has there been some increase in domestic adoption? Occasionally a little. But not much.

In any event, 10 to 14 million kids are growing up in institutions worldwide. Are all those kids going to be placed in nurturing domestic adoptive homes? Of course not. At best a tiny percent 
will be. So should international adoption be on the table as an option for kids? I would think so if we cared about kids.

But policymakers ignore the research and ignore children's needs.

There is one positive aspect to Russia's horrendous shutdown of international adoption. Russia at least didn't try to say it was acting for the best interest of children. It essentially admitted this was a power play, using children as pawns in trying to retaliate against the U.S. In addition Russia's child rights commissioner stated that it would be good for Russia to hold onto its kids rather than send them to other countries. So no claim that Russia was acting for the best interest of children. That's helpful because, amazingly to me, and sadly, people often believe it when UNICEF or our Department of State or developing nations say they're shutting down international adoption to help children, to prevent terrible abuses that allegedly befall children in international adoption. Russia helps give the lie to such claims.

\section{BAD RESEARCH PROMULGATED \& USED TO PROMOTE BAD POLICY}

What do I mean by bad research? I mean research that is dishonest, that claims that the best interest of the child should govern, but then fails to evaluate programs with a view to child interests. I mean research that is designed to serve a predetermined family preservation agenda, research designed to vindicate that agenda rather than genuinely evaluate it. I mean research that asks narrow questions, questions such as whether a program furthers family preservation, without asking whether more family preservation serves child best interests. I mean research that gives misleading, even dishonest answers.

My first example of bad research is the early research related to intensive family preservation services (IFPS). This is the best-known example of bad research. Indeed, many people now cite this research as an example of what used to be done in the bad old days.

IFPS was the darling of the child welfare establishment in the $1970 \mathrm{~s}$ through ' $90 \mathrm{~s}$. The idea was an unconvincing one from the get-go. It was that abuse and neglect were caused by a momentary crisis in a family. The program was to send in social workers $24 / 7$ for six weeks, to help fix the problems and get the family through the crisis. The goal was to keep as many kids as possible home in the meantime. Kids identified as abused and neglected were defined as "at risk of removal," rather than as at risk for further abuse and neglect. The risk of removal could be solved by not removing them. The program was sold in part on the basis that it would save the state money by reducing foster care costs. 
The powerful Edna McConnell Clark Foundation worked with others both to promote this program, and to conduct the research evaluating the program. This research asked an extremely narrow question - does this program succeed in keeping kids at home, more kids than would have been kept at home under traditional policy? This is a classic example of the problem in child welfare research. We have a program designed to keep kids at home. Now we will study whether we succeeded in keeping kids at home. And then we will claim success based on achieving our goal. Oddly enough the research claim for success in these terms turned out not even to be accurate. It wasn't clear that IFPS had really succeeded in keeping more kids at home and thus reducing foster care costs.

But the more profound problem with the research was that it never asked whether the kids kept home by IFPS programs were at greater risk in maltreatment and other terms than they would have been had they been removed. Given the rather obvious risk to children identified as victims of maltreatment from not being removed, this was an outrageous omission.

Wouldn't you think that that child welfare research would ask the question whether a program advances or undermines child welfare?

By the late 1990s, the field had generally recognized this self-serving research as a scandal. For example, Amy Heneghan published in 1996 a review of the IFPS research which amounted to a devastating critique. She noted its methodological failures, its failure to prove success in reducing removal, its failure to focus on child wellbeing including, for children kept at home, whether maltreatment had reoccurred, or how other measures of wellbeing were affected, and its failure to compare IFPS to alternatives such as adoption and foster care. She concluded that IFPS may be "placing children at risk."

Today many concede that the early IFPS research was a disgrace. However most act as if this is a unique example, when in fact the exact same types of problems characterize other child welfare research.

Perhaps the most significant recent example of egregious research misconduct has been in service of the Racial Disproportionality Movement, one of the latest forms family preservation ideology has taken. I wrote an article several years ago challenging this Movement, titled "The Racial Disproportionality Movement: False Facts and Dangerous Directions." Our Harvard Child Advocacy Program followed up on this article by co-sponsoring a conference on the topic with a highly respected research center called Chapin Hall at the University of Chicago.

The Racial Disproportionality Movement was led by the Casey Alliance, which consisted of the extraordinarily rich and powerful Casey Foundations together with some non-profit advocacy groups. They managed to get the sign-on of virtually every establishment organization in the child welfare field including, for example, the Child Welfare League of America, the American 
Bar Association Center on Children and Law, the North American Council on Adoptable Children, the Pew Commission on Foster Care, the National Association for Public Child Welfare Administrators, the National Council of Juvenile and Family Court Judges, and the Administration on Children and Families of the U.S. Department of Health and Human Services. They got this support based in part on their claims about what the research showed, and in part on the general readiness of the child welfare establishment to go in the family preservation direction.

The Movement's goal was to reduce the removal of black kids from their homes into foster care, so that the black foster care percentage would match the black child population percentage. The goal was based on a claim of racial discrimination, a claim that current high rates of black child removal to foster care reflected discrimination by the child welfare system.

The discrimination claim was based on what I think was a seriously fraudulent use of research. So the claim was based primarily on a set of research reports called the National Incidence Studies or NIS, designed to measure the actual incidence of maltreatment, as opposed to the official statistics on maltreatment. These NIS reports, including the most-cited NIS-3, published in 1996, made the claim that black and white actual maltreatment rates were the same, and that since blacks were removed to and represented in foster care at higher rates than whites, you could assume that the system functioned in a racially biased way.

This NIS claim was cited in hundreds of other research reports, reports which were then used along with the NIS to justify policies designed to reduce the number of black children removed to foster care.

The Casey Alliance used its wealth both to promote policy advocacy on these issues and to fund related research. For example, the Alliance approached states throughout the country and said, we'll help you study your racial disproportionality problem, write the resulting report stating the nature of your problem, and then we'll help you solve your problem with appropriate new policies. If you read the research reports that resulted from this process you will see that the claims of bias almost all come back to the NIS claims.

So what did NIS-3 say specifically? NIS-3 said black and white maltreatment rates were the same, period. No footnote. This claim seemed more than a little surprising because there are so many reasons to think they wouldn't be the same. Blacks are at the bottom of the socioeconomic ladder, and all the most common predictors of maltreatment are associated with poverty. Indeed NIS-3 itself demonstrated a powerful correlation between poverty and child maltreatment.

So it was surprising that NIS found that black and white maltreatment rates were the same. 
Surprising and, as it turns out, simply not true. Nor did the NIS authors have any basis for thinking that the claim was true.

By the time we gave our Racial Disproportionality conference, NIS-4 had been published. In this report the NIS authors said that they now had a larger sample and had found a statistically significant difference between black and white maltreatment rates. An enterprising social scientist, Brett Drake, had dug out by the time of our conference the actual data from the earlier NIS reports, statistics that had been hidden away in a later-published gigantic appendix. His presentation at our conference demonstrated that the NIS-2 and NIS-3 studies showed similar differences between black and white maltreatment rates as those revealed in the NIS-4 report:

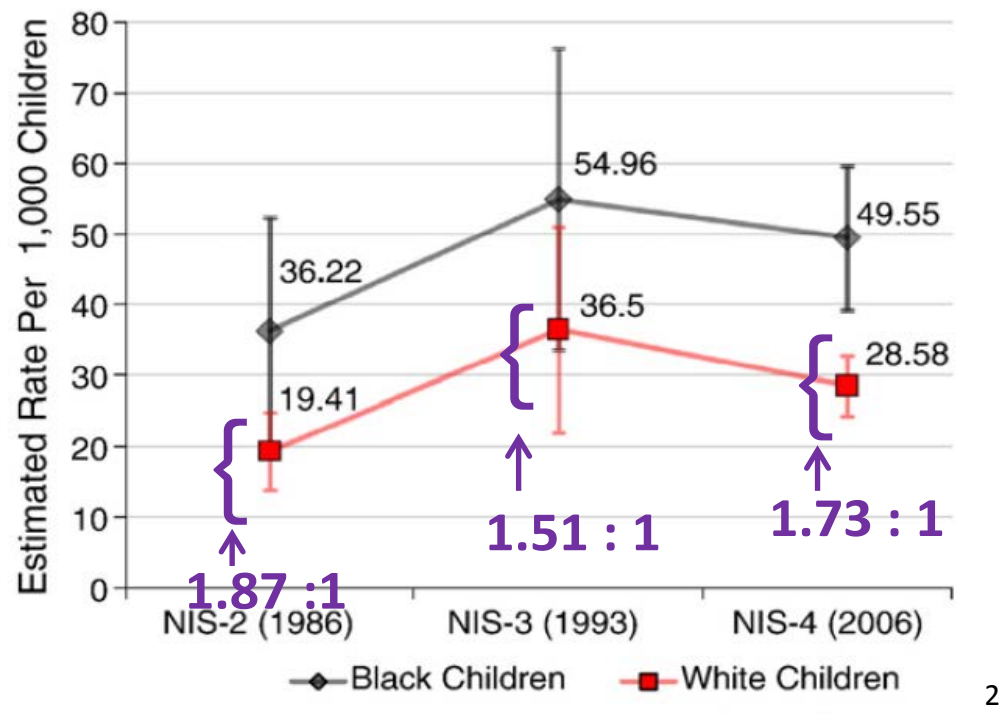

${ }^{2}$ Prof. Drakes's PowerPoint presentation, slide 12 at http://www.law.harvard.edu/programs/about/cap/cap-conferences/rd-conference/rd-conferencepapers/compatiblefinalrdconferenceppdrake.ppt, at conference held at Harvard Law School, Jan. 28-29, 2011, “Race \& Child Welfare: Disproportionality, Disparity, Discrimination; to see Prof. Drake’s video presentation, go to video 2 at http://www.law.harvard.edu/programs/about/cap/cap-conferences/rdconference/rd-video/rd-conference-index.html 
And the Drake presentation showed that the differences between actual black and white maltreatment rates revealed by NIS-2 through NIS-4 resemble the difference in black and white official removal rates:
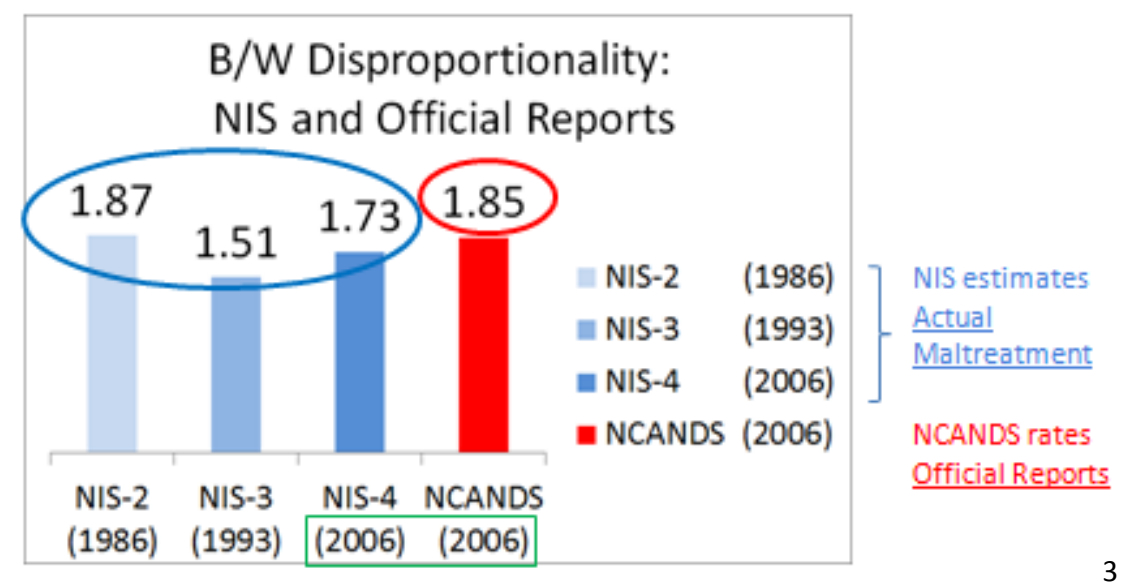

So there never was any basis in the NIS data for concluding that black and white actual maltreatment rates were either the same or meaningfully different from the official removal rates, and thus there never was any basis for presuming bias.

Yet here's what the NIS-3 authors had said:

The NIS-3 found no race differences in maltreatment incidence. The NIS-3 reiterates the findings of the earlier national incidence studies in this regard. That is, the NIS-1 and the NIS-2 also found no significant race differences in the incidence of maltreatment or maltreatment related injuries. Service providers may find these results somewhat surprising in view of the disproportionate representation of children of color in the child welfare population... The NIS findings suggest that the different races receive differential

${ }^{3}$ See Prof. Drakes's PowerPoint presentation at conference referred to supra n. 2, , slide 14, at http://www.law.harvard.edu/programs/about/cap/cap-conferences/rd-conference/rd-conferencepapers/compatiblefinalrdconferenceppdrake.ppt 
attention somewhere during the process of referral, investigation, and service allocation, and that the differential representation of minorities in the child welfare population does not derive from inherent differences in the rates at which they are abused or neglected. (NIS-3 Final Report, Page 8-7) (emphasis added).

Some version of that NIS-3 statement was repeated hundreds and hundreds of times in other research reports written and promoted by the Casey Alliance. That's the basis for the discrimination theory adopted by dozens of states which passed legislation designed to address their alleged racial bias problem, and a federal congressional committee recommending related federal legislation.

The only real difference between the actual underlying date for NIS-4 and the earlier NIS reports is that in the earlier studies there was not a big enough sample to find a statistically significant difference. But the NIS authors did not say that nor did they ever reveal (except hidden away in the later-published appendix) that they had found differences between black and white maltreatment rates. Instead these sophisticated social scientists stated that the rates were the same and thus racial bias could be assumed to be the explanation for removal rate differences.

I am not a social scientist, but I've read enough over the last three decades to know that the NIS-3 claim was not a fair or accurate statement based on the underlying data. Absence of proof that differences are statistically significant is not the same as proof that rates are the same. It provides no evidence whatsoever of discrimination. It's hard to understand how sophisticated social scientists could in good faith make the fundamental error reflected in the NIS-3 statement.

The NIS-3 authors and the Casey Alliance leaders all had many reasons to believe that actual black maltreatment rates were higher than white, and indeed likely reflected or exceeded official removal rates. They had the underlying NIS-2 and NIS-3 data revealed in the Brett Drake slides. They had the poverty-related predictors I talked about earlier. They had lots else that I wrote about in my Racial Disproportionality article including self-report studies, which showed blacks admitting to much higher rates of abuse and neglect than whites, and suspicious death research, which showed much higher black child death rates than white. They had all sorts of evidence indicating that black maltreatment rates were much higher than white. They chose to ignore all of this in favor of the NIS-3 claims that were so useful for their racial bias theory.

I will end with my final example of research problems, which has to do with what I learned in connection with early prevention and protection programs. My hope in challenging the Racial Disproportionality Movement was to persuade the child welfare field to focus on doing something to address the real problem - the fact that too many black children, as well as white, 
were victimized by maltreatment. If we really care about black kids, we should be trying to reduce maltreatment rather than pretending it doesn't exist.

So my Harvard Child Advocacy Program followed up on the Racial Disproportionality conference with a Brainstorming Workshop on early prevention and protection. I was hoping this would be a really upbeat event, focused on promising developments designed to prevent maltreatment upfront, and also to intervene more actively to protect children once maltreatment is identified.

And the Workshop did reveal some exciting ideas and programs. One was a new emphasis on a public health approach to prevention. Could we think about child maltreatment the way we think about disease, and plan to protect communities from maltreatment the way we try to protect them from being exposed to disease. A concrete suggestion here involved the use of early home visitation on a truly universal basis, reaching out to all new parents, and then targeting more intensive home visitation for the families in greatest need. Presentations describing a program in Durham County, North Carolina, illustrated how this could be done at a reasonable cost per child.

Another exciting idea presented was the use of family drug courts to reach substance exposed infants (SEI). Today we send almost all these infants home with their drug and/or alcohol abusing parents. Desperate, needy, hard-to-parent child going home with desperate, needy, addicted parent is a prescription for disaster. The family drug court programs that reach substance exposed infants are rare. But I invited to this workshop two programs with apparently promising programs designed to reach infants.

We also learned at the Workshop about our surprising ability to predict which infants out of all those born will be at risk for maltreatment. If we can predict with great accuracy which children will likely be victimized, then we should be able to design targeted prevention programs to prevent that victimization. Emily Putnam-Hornstein and Barbara Needell reported that, based on risk factors available in all infant birth records, they could predict that a child characterized by seven risk factors had an $89 \%$ likelihood of being reported for maltreatment before the age of five. No new laws needed to gather this information since it sits in existing birth records. And if you can predict with this level of accuracy which kids will be reported for abuse and neglect, you should be able to protect a lot of kids, at least if you are willing to make use of this information.

We also learned something really interesting about the need for more effective coercive intervention systems. Emily Putnam-Hornstein found that the vast majority - some $82 \%$-- of all children in California referred for maltreatment before their first birthday were kept at home rather than removed to foster care. Of those kept at home, more than half were referred again 
before the age of five. Out of those kept at home following substantiation of the charges and receiving services, $65 \%$ were re-referred by the age of five. Pretty stunning failure rates for our current family preservation system.

To me Emily's research suggests at least doing research that might illuminate for us whether kids would do better if we removed more to foster care, and moved more on to adoption. The maltreatment rate in foster care is less than one percent. The maltreatment rate in adoptive homes is lower yet, and lower than the rate in biological parent-child homes.

All this was exciting, but the Workshop also revealed how family preservation ideology limits reform potential in the child welfare field, how little people seem prepared to pick up on the potential of the Putnam-Hornstein and Needell research, and how sadly similar present-day research often seems to that now-oft-condemned IFPS research.

The research still often ignores what should be the central issue -- whether programs serve or disserve child interests. It still often simply assesses how well programs with a family preservation goal work to serve that goal.

And the early intervention home visitation programs continue to ignore a problem identified in the early history of home visitation - the fact that roughly one-third of the families offered home visitation refuse to participate. But those promoting home visitation continue to promote it as an entirely voluntary system. And if you even mention mandatory to anybody who believes in home visitation, they tend to get very upset. This is presumably at least in part because mandatory is seen as the kiss of death given the value placed by so many on adult autonomy rights and family preservation. But it's broadly understood that the one-third who refuse to participate in home visitation are the families where the children are most at risk.

At our workshop the "universal" Durham Connects home visitation program presented statistics demonstrating its success with those it reached, but nothing on what it might do to reach that final and vitally important one-third it failed to reach. Indeed the only promising work related to that troublesome one-third that Workshop participants mentioned was one project investigating whether financial and perhaps other incentives might be used to encourage participation in home visitation.

Both the family drug court programs at our Workshop demonstrated their loyalty to the family preservation goal. Both cited research statistics demonstrating the degree to which that goal had been served.

The most fully developed SEI program was one set in Sacramento, California. Its literature described the goal as being to keep every single substance-exposed infant, if at all possible, at home. It described the program research as demonstrating success in achieving that goal. This 
program dealt with many cases in which the infant at issue was the second, third, fourth, or fifth child born drug-affected to the same mother.

If we care about child welfare shouldn't we have research designed to compare how well substance-exposed infants do if kept at home as compared to those removed to foster care, and as compared to those moved relatively promptly from foster care to adoption? I think I know what that research would show. And I think one reason this kind of research isn't done is because it would not serve the family preservation agenda.

\section{CONCLUSION}

I will close with a visionary known to all of you, Henry Kempe, famous for his 1962 battered child syndrome article which helped transform, in a more child-friendly direction, our child welfare system. Kempe wrote another article that should have been seen as similarly groundbreaking, but has largely been ignored. It was called "Approaches To Preventing Child Abuse," and was published in 1976. In this article he states the following:

We must now insist that each child is entitled to effective comprehensive health care, and that when parents are not motivated to seek it, society, on behalf of the child, must compel it. It seems incomprehensible that we have compulsory education, with truancy laws to enforce attendance and, I might add, imprisonment of parents who deny their child an education, and yet we do not establish similar safeguards for the child's very survival between birth and age $6 \ldots$.

We must [work with problem families] first by persuasion and education and trying to be as helpful as we can, but if that fails, we must initiate active intervention through child protection services....

When marriages fail, we have an institution called divorce, but between parent and child, divorce is not yet socially sanctioned. I suggest that voluntary relinquishment should be put forth as a desirable social act - to be encouraged for many of these families.

When that fails, legal termination of parental rights should be attempted. However, such termination is a difficult thing to achieve in our country.... But each child is on a schedule of his own emotional development.... He needs loving parents right now, and the same parents, not a series of ten foster homes. For 20 years, courts have lectured me on the rights of parents, but only two judges in my state have spoken effectively on the rights of children....

The really first-rate attention paid to the health of all children in less free societies makes you wonder whether one of our cherished democratic freedoms is the right to maim our own children. When I brought this question to the attention of one of our judges, he said, "That may be the price we have to pay." Who pays the price? Nobody has asked the child.... 
Let us now resolve to fight for [our children's] total civil rights. Let us not, I beg of you, settle for anything less. 4

So basically Henry Kempe is saying that if parents won't agree to home visitation we should make it mandatory, just as we make education mandatory. He's saying that children, like adults, should have a right to divorce when the relationship doesn't work for the child. Given the child's urgent need for nurturing parents now, they should not be made to wait forever for that divorce. And Kempe is saying we must fight for child rights.

I agree. I think that Henry Kempe is right on. Child welfare policy needs to move in a more child-friendly direction. And child welfare research needs to illuminate rather than ignore child interests.

${ }^{4}$ C. Henry Kempe, Approaches to Preventing Child Abuse: The Health Visitors Concept, 130 Am. J. Dis. Child. 941 (1976) (emphasis added). 